УДК 330.362

Жданова Л.Л., д.е.н., професор

Одеський національний економічний університет

\title{
НАГРОМАДЖЕННЯ КАПІТАЛУ ТА ЕКОНОМІЧНЕ ЗРОСТАННЯ У ВІДКРИТІЙ ЕКОНОМІЦІ
}

Досліджено диспропорції, що виникають у процесі нагромадження капіталу в умовах циклічного розвитку економіки та можливості їх пом'якшення за допомогою чистого експорту. 3'ясовано різні наслідки такого коригування диспропорцій та протиріч для розвинутих та слабо розвинутих країн. Показано специфіку нагромадження капіталу в умовах фінансіалізації та віртуалізації економічних процесів, зростаючого потоку різноманітних віддзеркалених форм, в тому числі перетворених i ірраціональних.

Ключові слова: нагромадження капіталу, інвестиційні блага, споживчі блага, диспропорційність.

Zhdanova L.

\section{ACCUMULATION OF CAPITAL AND ECONOMIC GROWTH IN AN OPEN ECONOMY}

The imbalances of the process of capital accumulation in the conditions of cyclical economic development and the possibility of their mitigation by means of net exports are investigated. The different consequences of such an adjustment of disparities for developed and less developed countries have been identified. The peculiarities of capital accumulation in the conditions of financialization and virtualization of economic processes, a growing flow of various reflected forms, including transformed and irrational ones, are shown.

Key words: capital accumulation, investment goods, consumer goods, disproportionality.

Жданова Л.Л.

\section{НАКОПЛЕНИЕ КАПИТАЛА И ЭКОНОМИЧЕСКИЙ РОСТ В ОТКРЫТОЙ ЭКОНОМИКЕ}

Исследованы диспропорции, возникающие в процессе накопления капитала в условиях циклического развития экономики и возможности их смягчения с помощью чистого экспорта. Выяснены различные последствия такой корректировки диспропорций для развитых и слаборазвитых стран. Показана специфика накопления капитала в условиях финансиализации и виртуализации экономических процессов, растущего потока разнообразных отраженных форм, в том числе превращенных и иррациональных.

Ключевые слова: накопление капитала, инвестиционные блага, потребительские блага, диспропорциональность.

Постановка проблеми у загальному вигляді та їі зв'язок 3 важливими науковими і практичними завданнями

Пріоритетами економічної політики у сучасних умовах $\epsilon$ макроекономічні проблеми, насамперед - економічне зростання. Матеріальною основою економічного зростання, тобто позитивної динаміки обсягів виробництва товарів та послуг, є нагромадження капіталу, яке здійснюється у процесі макроекономічного кругообігу, безперебійний хід якого можливий лише за умов відповідності один одному потоків товарів та потоків доходів. Така відповідність автоматично, безпосередньо самим ринком не забезпечується. 3'ясування причин диспропорцій було об'єктом тривалих дискусій, у процесі яких стало ясно, що національну економіку необхідно розглядати як частину світової економіки, тобто як відкриту економіку. Яким чином завдяки світовому ринку коригуються диспропорції між товарами та доходами, що виникають у процесі 
макроекономічного руху капіталу, і якими є наслідки такої форми встановлення макроекономічної рівноваги, є головною науковою проблемою даної статті.

\section{Аналіз останніх досліджень, у яких започатковано вирішення проблеми.}

Сутність процесу нагромадження капіталу, його основні риси та протиріччя, пропорції та їх динаміку розглядають у своїх творах як класики економічної теорії, так i сучасні автори, іноземні - С. Амін, І. Валлерстайн, Ш. Хошимура та ін., і вітчизняні А. Л. Бикова та О.Ф. Івашина, О. Болховітінова, В. М. Геєць, В. Дементьєв, Н. І. Дучинська, П. С. Єщенко, О. Заруба, Б. Є. Кваснюк, І. Крючкова, В. Литвицький, В. Мандибура, Ю. Ніколенко, С. В. Онішук та М. В. Білоусенко, В. Н. Тарасевич, А. А. Чухно, Л. В. Шинкарук та ін. Дослідниками поставлено питання про головні диспропорції, що виникають у процесі нагромадження капіталу: невідповідність за вартістю і натурально-речовою структурою вироблених предметів споживання та грошових доходів населення, призначених для споживчих цілей; невідповідність виробничих потужностей, що створюються в секторі виробництва інвестиційних товарів та попиту національного бізнесу на елементи основного капіталу. Автори, що розглядали відмічені диспропорції пропонували різні підходи до їх подолання. Однак за межами уваги дослідників залишилося питання щодо розбіжностей наслідків подолання диспропорцій процесу нагромадження капіталу у відкритій економіці для розвинутих та слабо розвинутих країн.

Цілі статті. Виходячи зі сказаного, метою написання даної статті є зіставлення поглядів найвідоміших вчених і сучасних авторів на проблему нагромадження капіталу та на заходи економічної політики і дії суб'єктів ринку, що спрямовані на подолання диспропорцій у процесі макроекономічного кругообігу у відкритій економіці.

\section{Виклад основного матеріалу дослідження 3 повним обгрунтуванням отриманих наукових результатів.}

Головне питання теорії нагромадження капіталу - 3'ясування об'єктивних пропорцій у структурі валового товарного капіталу суспільства, або його статистичної форми - ВВП - за яких реалізація вироблених товарі та послуг здійснюватиметься безупинно. Складність дослідження полягає у тому, що сучасна економіка - це економіка технічного прогресу, за умов якого різні частини валового товарного капіталу суспільства змінюються різними темпами. В результаті формується розбалансованість складових частин ВВП за натурально-речовою формою та функціональним призначенням. Ще більше ускладнює проблему циклічний рух економіки, який названу розбалансованість посилює.

У дослідженні проблеми розбалансованості чітко сформувалися дві концепції класична та кейнсіанська. Враховуючи кейнсіанський підхід, який конкретизує та уточнює висновки класичного підходу, міркування вибудовуються у такий логічний ланцюжок. Перший видимий результат нагромадження капіталу - зростання виробленої товарної маси, яка має бути проданою і тоді здійсниться економічне зростання. Відтак, постає питання про попит на цю збільшену масу товарів: чи створено відповідну величину доходів, які дозволять купити цю збільшену товарну масу? Валова товарна маса складається зі споживчих благ (звичайних, які купують одержувачі заробітної плати, та високоякісних і статусного споживання, які купують підприємці та власники) та інвестиційних (які купує бізнес для відтворення і нагромадження капіталу). Покупцем ще є держава, але у валовій товарній масі вона купує теж споживчі та інвестиційні блага.

У короткостроковому періоді найбільшу частку споживчих благ купують одержувачі заробітної плати, які пред'являють попит на звичайні, прості споживчі блага, які власно і адресовані їм як покупцям. Якщо реальна заробітна плата зростає такими ж темпами, як і виробництво звичайних споживчих благ, що адресуються найманій праці, 
тоді розбалансованість цього сектора буде мінімальною, враховуючи еластичність попиту за доходом та граничну норму заощадження відповідних груп покупців. Проте, якщо заробітна плата зростає меншими темпами, ніж виробництво звичайних споживчих благ, розбалансованість стає значно більшою і виникає питання про суб'єктів попиту на цей приріст товарної маси, що утілена у звичайних споживчих благах. Одержувачі прибутків і рентних доходів такого попиту не висунуть, тому що купують споживчі блага у сегменті високоякісних та статусних товарів. Їх попит на звичайні предмети споживання вже від самого початку задоволено, розширяти вони можуть свій попит лише у своєму сегменті ринку споживчих благ. В результаті такого дисбалансу у національному доході протягом деякого часу частка заробітної плати зменшується, а частка прибутку і рентних доході зростає.

Проте, неможливість реалізувати деяку кількість споживчих товарів означає, що виробників споживчих товарів, не повернуть собі еквівалента спожитого капіталу і внаслідок цього пред'являть менший попит на товари інвестиційного призначення, що, у свою чергу, викличе у виробників останніх труднощі збуту.

Таким чином, невідповідність темпів зростання реальної заробітної плати та виробництва звичайних споживчих благ веде до розбалансування усієї економіки у цілому. У зв'язку з загрозою кризи постає питання про можливість коригувати названу невідповідність методами економічної політики та діями суб'єктів ринку. Один підхід, започаткований С. Сісмонді, апелює до держави, яка мусить не допустити відміченої розбалансованості: «Завдання з'єднати знову інтереси тих, хто бере участь разом в одному і тому ж виробництві, а не ставити їх в опозицію, є справа законодавця» [1, с. 216]. Законодавець, дійсно, враховує інтереси всіх тих, хто бере участь у виробництві, проте менші темпи зростання заробітної плати по відношенню до зростання виробництва $\epsilon$ передумовою зростання прибутків бізнесу, що дозволяє розширяти виробництво, створювати нові підприємства і навіть нові галузі і завдяки цьому розширяти зайнятість та підвищувати заробітну плату. Таким чином, перед економічною політикою держави постають дві проблеми: стимулювання нагромадження капіталу завдяки зростанню прибутків, тобто стимулювання економічного зростання; або забезпечення незмінної пропорції поділу національного доходу на заробітну плату та прибутки і рентні доходи, тобто не допустити економічної кризи. Вирішенням проблеми диспропорційності може стати робота на закордонні ринки [2]. Цей погляд отримав логічне обгрунтування у теорії Дж. М. Кейнса [3]. 3 цього часу дослідження нагромадження капіталу у зв'язку 3 економічним зростанням набуває сучасного вигляду. Дослідницькі зусилля концентруються на питаннях економічних (ресурсних) можливостей і обмежень зростання національного виробництва і його динаміки в глобальній економіці

Практичні рекомендації концепції Дж. М. Кейнса спрямовані на подолання спаду та створення умов для економічного зростання за рахунок більш повного використання наявних ресурсів і досягнення повної зайнятості. Цим міркуванням властиво певне протиріччя. Суть його зводиться до наступного. Економічний спад характеризується тим, що споживчі витрати скоротилися, зросло безробіття. Відповідно до цього в торгівлі з'являються наднормативні запаси товарів. Торгівля починає подавати сигнали виробництву про необхідність скорочення обсягів поставок. I в цих умовах зростання труднощів збуту кейнсіанська теорія пропонує перетворити грошові заощадження в інвестиції. У зв'язку з цим виникає питання: навіщо? Попит вже скоротився, отже, треба скорочувати виробництво. Однак, якщо знайти нових споживачів, при цьому стільки, щоб вони могли розкупили запаси товарів у торгівлі, що виросли в результаті спаду виробництва, та купити приріст товарів, отриманий за рахунок нових інвестицій, тоді, 
дійсно, треба перетворювати заощадження в нові інвестиції. Де взяти цих нових покупців? Відповідь Дж. М. Кейнса - створити їх за рахунок держбюджетних витрат. Класична школа політекономії вважала, що держбюджет за допомогою податків лише переносить попит з одних суб'єктів на інших, тому бюджетні витрати в принципі нічого не змінюють. Можлива інша відповідь: бюджет створює новий попит за допомогою дефіцитного фінансування витрат. Однак кейнсіанський підхід не враховує одну важливу обставину. Економічний спад настає після насичення потреб, властивих науково-технічному рівню виробництва в період попереднього підйому. Труднощі збуту i зростаючі запаси пов'язані не тільки зі зменшенням доходів i, відповідно, витрат споживачів. Ці труднощі пов'язані із насиченням потреб. Саме з цієї причини починають рости заощадження як відкладений попит. Кейнсіанська доктрина не виділяє цю частину в загальному обсязі заощаджень, вважає всі заощадження негативним моментом, i спрямована на те, щоб всі їх перетворити в інвестиції. Однак, методи стимулювання попиту навряд чи торкнуться тієї частини заощаджень споживачів, яка представляє їх відкладений попит. Щоб ці заощадження надійшли на ринок, там повинен з'явитися новий товар. Саме це, як правило, відбувається в період переходу економіки від циклічного спаду до економічного піднесення. Попит на новий предмет споживання, на необхідні для його виробництва засоби виробництва, серед яких теж повинні бути нововведення, створює стимули для перетворення заощаджень в інвестиції. Якщо ж сукупний попит стимулюється в умовах слабких можливостей для здійснення інновацій, цілком обгрунтованою виглядає орієнтація виробництва на зовнішній ринок. Чистий експорт є однією із складових частин сукупного попиту в моделі Дж. М. Кейнса. Проте, де гарантії, що зовнішньому ринку потрібні товари, надлишкові на внутрішньому ринку тієї чи іншої країни?

Не менш складною проблемою кейнсіанської моделі сукупного попиту є частина, яка представлена попитом бізнесу на інвестиційні товари. Розвиненим країнам притаманний пульсуючий характер попиту на елементи основного капіталу, пов'язаний 3 циклічним характером руху розвиненої ринкової економіки. Економіка переживає істотне зростання попиту на елементи основного капіталу в одні періоди економічного циклу, а потім не менш суттєвий його спад в інші періоди циклу. При цьому виробничі потужності, що випускають машини і обладнання, створюються для задоволення підвищеного попиту періоду економічного піднесення. Виникає питання: що робити 3 надлишковими потужностями в секторі виробництва інвестиційних товарів при спаді попиту на елементи основного капіталу [4, с.247-251, 274-277].

Прямої відповіді на це питання кейнсіанська теорія не дає. Однак присутність у формулі сукупного попиту елемента «чистий експорт» переносить макроекономічну рівновагу такої економіки з національного ринку, на світовий. Виходячи з цього, подальшою конкретизацією проблеми повинна стати деталізація чистого експорту 3 точки зору об'єктів пропозиції.

У періоди циклічного падіння національного попиту на елементи основного капіталу цілком логічним виглядає переорієнтація випуску машин і устаткування на світовий ринок, що дозволить забезпечити більш рівномірне завантаження продуктивного капіталу галузей машинобудування. Однак для цього на світовому ринку повинен бути досить стійкий, постійний попит на елементи основного капіталу (машини і обладнання). Крім цього, покупці таких товарів повинні мати можливості оплатити їх вартість, або бути кредитоспроможними для міжнародних кредитних установ. Отже, на світовому ринку повинні бути країни нетто-експортери та країни нетто-імпортери. Відносно країн нетто-експортерів зрозуміло, що це розвинуті країни, на базі економіки яких і розроблена теорія Дж. М. Кейнса. Позитивну величину чистого експорту для них 
забезпечують нетто-імпортери, тобто менш розвинуті країни. Таким чином, у дослідженні макроекономічного кругообігу можна виділити два напрямки. Один з них пов'язаний з економікою розвинених країн, інший - з економікою країн, що відстали у своєму розвитку.

Стосовно економіки розвинутих країн можливості подолання диспропорцій у структурі валового внутрішнього продукту, тобто надлишкове виробництво речових елементів основного капіталу, пов'язують з позитивною величиною чистого експорту. Подолання диспропорцій у структурі національного доходу досліджує вже посткейнсіанство, насамперед Дж. Робінсон. Вона доводить, що цілком можливо збільшення продуктивності без збільшення капіталоозброєності праці. Це відбувається, коли капіталозаощаджуючі винаходи врівноважуються винаходами працезберігаючими, в результаті чого технічний прогрес стає «нейтральним». Нейтральний тип технічного прогресу, підвищення заробітної плати відповідно до зростання продуктивності праці, існування вільної конкуренції Дж. Робінсон називає ідеальними умовами, «золотим віком» економічного зростання. У цих ідеальних умовах нагромадження капіталу залежить тільки від темпів технічного прогресу і приросту зайнятості. Порушення цих умов $є$ причиною нестабільності економіки. Залишається лише одне питання: яким чином можна забезпечити відповідність темпів підвищення заробітної плати до темпів зростання продуктивності праці? Ії̈ відповідь: перешкодити тенденції до зниження заробітної плати може боротьба профспілок. Якщо в результаті цієї боротьби заробітну плату вдається підвищити в тій же мірі, в якій росте виробництво на душу населення, перешкоди для нагромадження капіталу і економічного зростання знищуються [5, p. 100].

Проблематика процесу нагромадження капіталу у менш розвинутих країнах розглядається в межах теорій залежності і периферійного капіталізму. 3 досліджень випливає, що ці країни відстали в становленні економічних відносин ринкового типу, інститутів ринкової економіки, і ще більше - в становленні інститутів громадянського суспільства.

Дослідники відзначають, що в економіках країн периферійного капіталізму відсутні внутрішні джерела інноваційного розвитку [6, с. 180-196]. У той же час прискорений науково-технічний прогрес в розвинених країнах, світова презентація його досягнень створюють в менш розвинених країнах потребу в сучасних товарах, перш за все споживчого призначення. Потреба купувати такі товари формує мотиви поставок на світовий ринок власної конкурентоспроможної продукції. При цьому вибір спеціалізації здійснюється на основі принципу порівняльних переваг. В результаті ефективними виявляються галузі добувної промисловості та сільського господарства, тобто такі, які виробляють предмети праці, необхідні для подальшої обробки. Одночасно ці галузі потребують засобів праці (машин і обладнання), які національні промислові комплекси створити не здатні. Точніше, створити їх вони можуть, але такі засоби праці за технікоексплуатаційними та економічними характеристиками поступаються зразкам, що поставляються на світовий ринок розвиненими країнами. В результаті виробники, які застосовують вітчизняні машини і обладнання, втрачають конкурентоспроможність. Цілком зрозуміло, що вони відмовляються від вітчизняних засобів праці. Капітал менш розвинених країн в процесі міжгалузевої конкуренції, тобто міжгалузевої міграції залишає сферу виробництва засобів праці і переміщується в сферу виробництва предметів праці. Таке переміщення тільки абстрактно-теоретично можна трактувати як міграцію капіталу. У конкретній дійсності вилучити капітал з галузі, яка вступила в смугу занепаду, неможливо. Його вартість зникає разом з руйнуванням носіїв цієї 
вартості - верстатів, машин, обладнання. Переміщується тільки накопичений прибуток і кредитні ресурси. Завдяки такому здійсненню процесу міжгалузевої міграції капіталу перебудова галузевої структури економіки супроводжується руйнуванням продуктивних сил в галузях, які переживають спад. А враховуючи, що капітал переміщується у видобувну галузь і сільське господарство, - процес міжгалузевої міграції капіталу супроводжується ще й примітивізацією галузевої структури виробництва. Міжнародна спеціалізація, що формується таким чином, все більше і більше ускладнює розвиток галузей обробної промисловості у відсталих країнах. В результаті цих безперервних процесів розвиненим країнам протистоять слаборозвинені, без попиту яких на елементи основного капіталу розвинені країни будуть стикатися 3 хронічним перевиробництвом капіталу в продуктивній формі в галузях машинобудування, а внаслідок цього - і 3 труднощами збуту товарного капіталу в цілому.

Висновок дослідження нагромадження капіталу як цілісного процесу, що охоплює економіку всього світу: для балансування сукупного попиту та сукупної пропозиції необхідний світовий ринок та присутність на ньому поряд з розвинутими країнами країн, що відстали в своєму розвитку.

Фінансіалізація і віртуалізація економічних процесів, які відбуваються в сучасних умовах у розвинутих країнах, ставлять питання про нагромадження фіктивного, а потім і віртуального капіталу.

Нагромадження фіктивного капіталу безпосередньо пов'язано 3 кредитногрошовою політикою Центрального банку країни. Зниження облікової ставки відсотка, що здійснюється з метою стимулювання сукупного попиту, веде до зростання курсової оцінки акцій і облігацій. В результаті на вторинному ринку цінних паперів роздувається своєрідна «бульбашка», наповнена повітрям очікування високих доходів. Зростаючі доходи від купівлі-продажу цінних паперів найчастіше продовжують функціонувати у фінансовому секторі, не мігруючи в реальний сектор економіки. У суб'єктів ринку складається перебільшене уявлення про вартість активів, інвестованих в реальний сектор, однак відзначене зростання ресурсів носить в значній мірі лише віртуальний характер.

Віртуалізація економічних процесів отримала своє відображення в концепціях соціального, культурного, символічного капіталу. Ці поняття входять в науковий обіг у зв'язку з теоретичним відображенням пошуків фірмами можливостей підвищення ефективності виробництва.

Соціальний капітал вимірюється кількістю і ефективністю соціальних структур, що сприяють безконфліктному, отже, з меншими витратами, веденню бізнесу. Культурний капітал становлять все культурні ресурси, якими володіє індивід. Близький до нього за змістом символічний капітал - це престиж, який дають різноманітні відзнаки, нагороди, титули і т. п. Найяскравіше він проявляється в брендах, які в умовах перенасичених ринків, з величезною різноманітністю взаємозамінних товарів, переводять конкуренцію зі сфери матеріального виробництва у віртуальну реальність, де створюються уявні особливі якості товару або фірми, що цінуються споживачами або інвесторами вище, ніж фактично зроблене. Бренд стає об'єктом купівлі-продажу, однак отримати вигоду від такої покупки інвестор може, лише організувавши власне виробництво під маркою купленого бренду і підтримуючи і розвиваючи його імідж. Це саме можна сказати і про соціальний капітал. Напрацьовані фірмою соціальні структури і зв'язки можуть бути об'єктом купівлі-продажу тільки разом із самою фірмою, і отримувати вигоду від їх існування інвестор може лише за умови підтримання і зміцнення виробництва, а разом 3 ним і соціальних зв'язків, успадкованих при покупці фірми. 
Таким чином, сучасна соціологія, вводячи в науковий обіг безліч часткових трактувань капіталу, множачи його форми і розмиваючи його сутність, створює зростаючий потік різноманітних віддзеркалених форм, в тому числі перетворених i ірраціональних.

Віддзеркалений характер зазначених форм зовсім не означає, що вони не належать до об'єктивного світу. Навпаки, об'єктивний світ 3 їх появою збагачується i ускладнюється, оскільки надбудова віртуальних форм, здіймаючись над реальним базисом суспільно-господарського життя, перетворює його відповідно до імперативу сучасного розвитку: продукти знаходять штрих-коди, комерційні організації - бренди, індивідуальні суб'єкти - імідж [7, с.312-313].

Однак, не дивлячись на таке помітне ускладнення економіки, надбудовані віртуальні форми капіталу самі по собі нагромаджуватись не можуть і економічного зростання не забезпечують. Будучи тінню реального капіталу, вони існують лише разом 3 ним, в процесі його кругообігу. Об'єктом нагромадження продовжує залишатися реальний капітал, який забезпечує зростання господарської системи і визначає характер ії еволюції.

Висновки. В процесі макроекономічного кругообігу капіталу, що здійснюється в умовах технічного прогресу, неминуче виникають диспропорції. Вони породжуються соціально-економічною природою капіталу, тобто мають об'єктивний характер. Ускладнення і глобалізація економіки відповідно ускладнюють і диспропорції. Хоча розвиток світового ринку і глобального капіталу в деякій мірі пом'якшують протиріччя відтворювального процесу в економічно розвинених країнах, проте це пом'якшення одночасно призводить до замкненого кола відсталості і їі консервації к менш розвинених країн. При цьому в пастку відсталості ці країни потрапляють в силу неконкурентоспроможності їх продукції переробних галузей, що веде до міжгалузевої міграції ресурсів у видобувні галузі і сільське господарство, i, відповідно, до примітивізації галузевої структури економіки менш розвинутих країн.

\section{Список бібліографічного опису:}

1.Сисмонди Симонд Ж. Новые начала политической экономии или О богатстве в его отношении к народонаселению / Симонд де Сисмонди Ж. Том I. - М.: Государственное социально-экономическое издательство, $1936 .-386$ с.

2.Люксембург Р. Акумуляція капіталу До економічного обгрунтування імперіалізму /Пер. 3 нім. Володимира Щербаненка / Р. Люксембург. - Київ: Rosa-Luxemburg-Stiftung в Україні; АРТ-КНИГА, 2019. - 352 с.

3.Кейнс Дж. М. Общая теория занятости процента и денег / Дж. М. Кейнс. - М.: Прогресс, 1978. - 494 с.

4.Хаберлер Г. Процветание и депрессия: теоретический анализ циклических колебаний / Готфрид Хаберлер Челябинск: Социум, 2005. - 474 c.

5.Robinson J. (1956). The Accumulation of Capital. London: Macmillan \&Co Ltd.

6.Райнерт Э.С. Как богатые страны стали богатыми, и почему бедные страны остаются бедными [текст] / пер. с англ. Н. Автономовой; под ред. В. Автономова; Гос. ун-т Высшая школа экономики. - М.: Изд. дом гос. ун-та Высшей школы экономики, 2011. - 384 с.

7.Ушаков А. С. Развитие виртуальных экономических отношений и воспроизводство фиктивного капитала //Общество и право. 2014. №3 (49). С.312-317.

\section{References:}

1.Sismondi, Simond J. (1936). Novyye nachala politicheskoy ekonomii ili O bogatstve v yego otnoshenii k narodonaseleniyu [New principles of political economy or On wealth in its relation to population]. (Tom I) Volume I. M.: State socio-economic publishing house [in Russian].

2.Lyuksemburh, R. (2019) Akumulyatsiya kapitalu Do ekonomichnoho obgruntuvannya imperializmu /Per. z nim. Volodymyra Shcherbanenka [The Accumulation of Capital. To the Economic Justification of Imperialism / Trans. from German by Volodymyr Shcherbanenko]. Kyiv: Rosa-Luxemburg-Stiftung v Ukrayini; ART-KNYHA [in Ukrainian].

3.Keyns, Dzh. M. (1978). Obshchaya teoriya zanyatosti protsenta i deneg [General theory of the employment, interest and money]. M.: Progress [in Russian].

4.Khaberler, G. (2005). Protsvetaniye i depressiya: teoreticheskiy analiz tsiklicheskikh kolebaniy [Prosperity and Depression: A Theoretical Analysis of Cyclical Movements]. Chelyabinsk: Sotsium [in Russian].

5.Robinson, J. (1956). The Accumulation of Capital. London: Macmillan \&Co Ltd.

6.Raynert, E. S. (2011). Kak bogatyye strany stali bogatymi, i pochemu bednyye strany ostayut'sya bednymi [How rich countries became rich, and why poor countries remain poor]. M.: Publishing House of State University of Higher School of Economics [in Russian].

7. Ushakov, A. S. (2014). Razvitiye virtual'nykh ekonomicheskikh otnosheniy i vosproizvodstvo fiktivnogo kapitala [Development of virtual economic relations and the reproduction of fictitious capital]. Obshchestvo i pravo - Society and Law, 3 (49), 312-317 [in Russian]. 